\title{
先天性内反足難治例に対する後内側解離術（Turco）
}

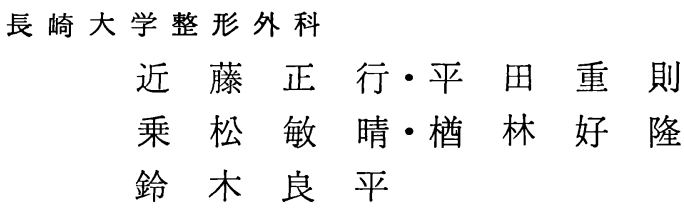

\section{Experiences of Treatment of the Resistant Congenital Clubfoot with Turco's Posteromedial Release Method}

by

\author{
M. Kondo, S. Hirata T. Norimatsu, \\ Y. Narabayashi and R. Suzuki \\ Department of Orthopaedic Surgery Nagaski University \\ School of Medicine
}

\begin{abstract}
Since 1973, we have treated the resistant congenital clubfoot with postermedial release method described by Turco (1971). An investigation was made for tracing such operated case whose followed-up period was over a year.

The total cases operated from 1973 to 1977 are forty-four feet of thirty-one cases, of which, thirty-one feet of twenty-two cases were followed up over a year. In the early, the operated age was about at two years of age, recently, the operated age was about at a year of age.

Except five feet of five cases two operated in the early, and a foot of which the Kirschner's pin dropped out during casting period, all were got good results, however, this method can not correct the adducted forefoot and cavusfoot, for these, further surgical treatment is necessary.

Considering of the development of the foot, of atrophy of the calf mucsles, it is better to shorten the period of casting or prosthesing for surgical treatment early.
\end{abstract}

\section{はじめに}

先天性内反足に対する治療として過去数多くの方法 が考案されているが, 今もって難治例および再発例に は頭を痛めるとてろである.

今回われわれは，そのような例に対して 1971 年 Turco の発表した後内側解離術を施行し，その 1 年 以上経過した症例について検討した. われわれの行な った治療法は図 1 亿示す通りである. 矯正ギプスで内 転内反の矯正位は得られたが，なお尖足が矯正されな いむのには後方解離術を旋行し, また内反矯正に頑固 に抵抗するすのおよび再発例には後内側解離術を施行 している.

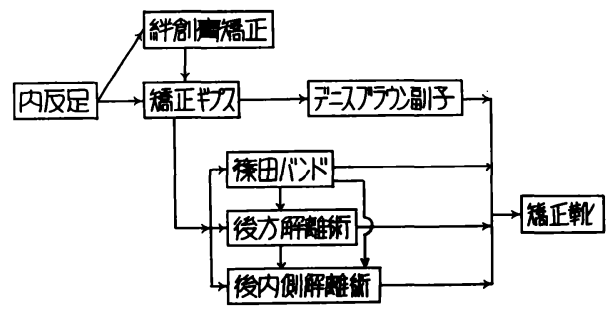

四の我Qが行た治宾法

図 1 我々が行つた治療法

対 象

昭和 48 年春 から 52 年春 までに本法を試みたもの 
は, 31 例 44 足で，そのうち 1 年以上経過した例は 22 例 31 足である. 男女比は 16 対 6 で男に多い.

手術時年令は生後 10 力月から 73 力月で, 初期は 2 才前後に本法を施行していたが，最近では 1 才前後に 施行している.

\section{手術方法ならび後療法（図 2)}

ほぼ Turco の原法に準じている.

第 1 中足骨から内顆の下を通ってアキレス腱までい く内側切開でアキレス腱に沿った弓状切開は全く不要 である．皮膚切開が終わると次の順で露出する，後脛 骨筋，長趾届筋腱，神経血管束，長母趾届筋腱，アキ レス腱. 神経血管束は静脈をめやすにする.

以上の露出を終わり次の順序で解離を行なう. (1)後 方解離術, (2)内側解離術, (3)距骨下解離術.
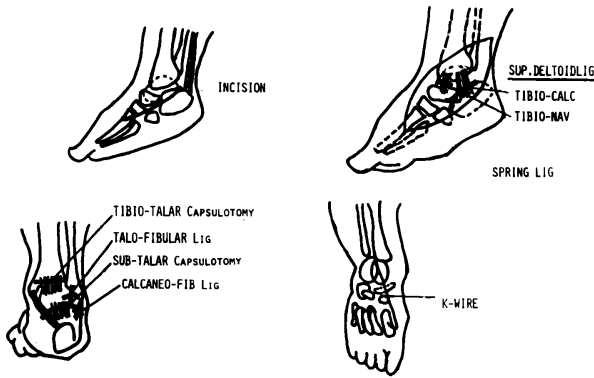

图 2 JBJS Vol 53A No. 3 p. 481 上り引用

\section{後方解離術}

内側および距骨下解離を容易にするために行なう。 アキレス腱を $Z$ 状に延長し，乙れを分けると脛骨の下 縁が出てくる. そこで関節包を切開する. 次のポイン 卜は距骨下関節の後方要素, 踵腓靱帯である，後方要 素の最終段階として踵骨上で三角靶帯の後方を切離す る.

\section{内側解離術}

後脛骨筋腱を内顆の直上で切る. 次に底側踵舟靶帯 (spring ligament) を軟骨膜下に，載距突起からは がす.さらに三角勒帯の浅層を切離する。

\section{距骨下解離術}

足を外反し直視下に距踵骨間靱帯を切離する．舟状 骨の可動性は 2 分靶帯 (Y 靶帯) を切ることにより完 成する. 以上で 全ての解離を 終了して距舟関節整復 後, キルシュナー鋼線で距舟関節を固定する.

\section{術 後}

術後のギプスは大腿より足尖までまく，膝関節は軽 度届曲位で内反足は軽度矯正位に保持する. その後 3 週で巻きかえをし，その時抜系する．キルシュナー鋼 線は 6 週で抜去するが，乙の時にギプスの巻きかえを する.

最初の 2 力月は $\mathrm{A} / \mathrm{K}$ ギプスで固定する.ひきつづ き $\mathrm{B} / \mathrm{K}$ ギプスを巻き，計 4 力月間ギプス固定する. その後矯正靴を使用し，デニスブラウン副子は使用し ない，乙の点ののみが，原法と異なる点である．

\section{成}

判定の方法として臨床的にはっきりしたものがない ので，われわれは立位にて後方より見て踵骨内反の有 無で良之不可の 2 つ分けた。その結果は 22 例 31 足 のうち良は 17 例 25 足であり，不可は 5 例 6 足であっ た. 不可の内 5 例 5 足は初期の例であり， 1 例 1 足は ギプス内でキルシュナー鋼線の抜けたものである.さ らにその術前および術後で最も現在に近いレ線の計測 および背屈度を 計测して，その臨床所見と比べてみ た. 計測は側面距踵角, 側面距腿角, 前後距踵角, 前 後第 1 中足骨距骨角，第 5 中足骨踵骨角について行な った.なお踵骨については長軸と思われるところを基 準とした. その結果第 1 中足骨距骨角，第 5 中足骨踵 骨角は正常ではほぼ 0 度といわれているが，われわれ の例では術前術後とも0 度を中心に非常にばらつきが 多く何とあいいがたい.

次に前後距踵角であるが， 22 足中 15 足で前方開角 が術前より増大しているが， 10 度以上増大したもの は20 例しかない．また術前より減少しているものも 7 例ある.

背届に関しては, 術後ほとんどの例で改善している が, 逆の例も少数だがある.（計測ミスかもしれない.)

側面距腿角においては，改善 17 足うち 14 足が 10 度以上の改善を示し，悪くなったものも6 足ある。

（レ線撮影時正確に最大背屈させたかどうか不明）

最後に側面距踵角であるが，乙れでは臨床上良と判 定したものは全例 ほぼ 30 度以上を示している．以上 より臨床所見と最も良く相関すると思われるのは側面 距踵角であると思う（図 3 )

\section{考案}

内反足治療の過程で，ギプスを長く巻いたものの中 

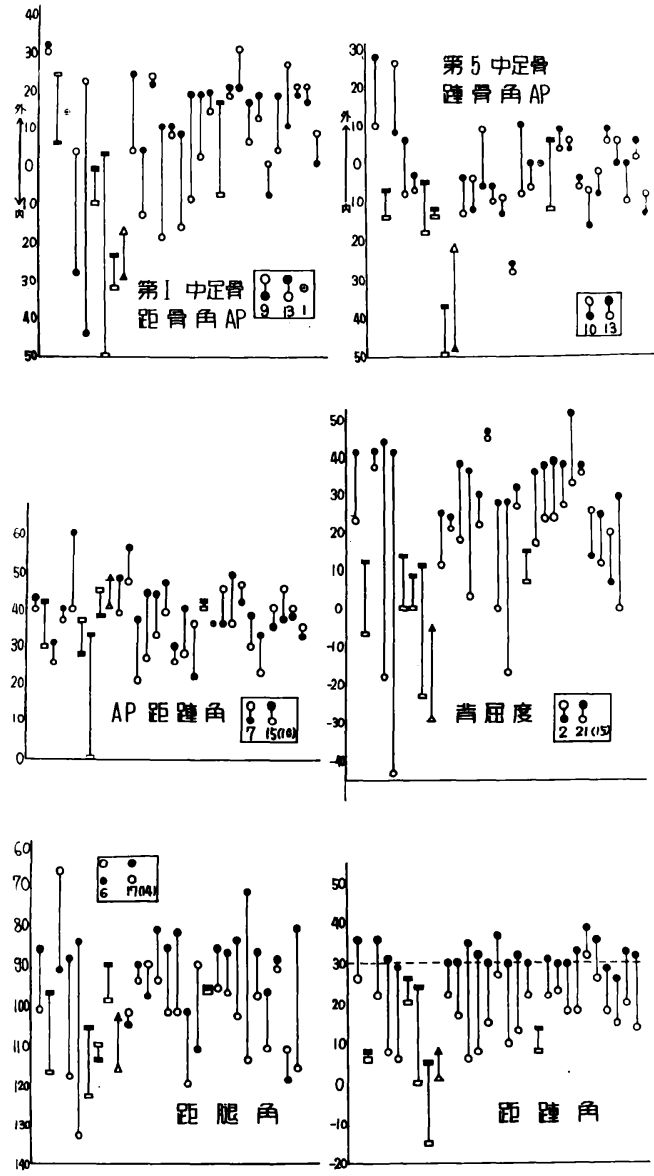

縦軸はそれぞれの角度を示す。

横軸は手術時年令順にならべたるの

○は成樍良のものの術前

は成樍良のものの術後 は成績不良

$\triangle$ はキルミューの抜けた例

図3

には足成長障害, 下腿筋萎縮および関節症などの合件 症が認められるが，てのような合併症をおてさせない ためには, できるだけ早期に, 荷重関節である距腿お よび距骨下関節の早期整復を目ざして, 観血的療法に きりかえるべきではなかろうかと考えている.

過去われわれは観血的治療として, 内側解離術およ び後方解離術の 2 段階手術や後方解離術のみを施行し てきたが，結果は不満足な例も多い，そこでわれわれ は Turco の後内側解離術を使用してみた. その長所 としては, 皮㡺切開線が短かく皮膚壊死がないこと,
一段階手術であり尖足内反の矯正が一気にしかも充分 にできること．また整復位の保持もキルシュナー鋼線 一本で可能であることなどである.

再発に関しては，（いまだ術後経過年数は短かいの であるが）現時点ではたしかにそれを防止できる方法 と思っている. われわれはギプス固定後，デニスブラ ウン副子は使わず，矯正靴を使用させているが，てれ であ再発の心配なく充分であると思う．ての点よりみ てギプスによる4カ月の固定は親にとってあ，子にと ってあきついかすしれないが，4 力月をすぎるとほぼ 安心できる状態となる。

次に拘樎についてであるが，術後背届ができるよう になるのは当然だが，底屈が制限されるあまり，つま さき歩行ができなくなるととがある．乙れは 2 才前後 で手術した例に多く，より早期に手術を施行したもの には少ないようである．ちなみに底届ができるものは ほぼ 1 年でつまさき歩行が可能となった.

次に手術手技上の注意すべき点であるが，Y 勒帯に ついて（われわれは全例切離したのであるが），その 切離の際直視下にできないととが多いので距骨頭の軟 骨をきずつけかねない。キルシュナー鋼線にて整復を 誤まったものは全例成績不可であり，整復位の判定が むずかしいのあ確かであるので，乙の点は大いに注意 すべきことである．また創感染はなかったが，キルシ ユナ一鋼線の抜けたあのが，成績の非常に悪かったも の 1 足を含み 4 足もあるので，キルシュナー鋼線は充 分ギプス内に巻き込む必要があると考えられる.

臨床所見とレ線との関係は，先に述べたように側面 距踵角が最も相関すると思われる.

最後に本法においては前足部内転や凹足の矯正はで きないので，乙れらの遺残変形に対しては追加手術を 必要とする.なおやや年長児に対しては Evans の手 術を施行している.

\section{結語}

後足部変形に対して Turco 法による後内側解離術 を施行し，比較的良好な成績を得たので報告した。

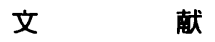

1) Turco, V. J.: J. B. J. S., 53-A, 477, 1971.

2) Evans, D.: J. B. J. S., 43-B, 722, 1961.

3) 糟谷ほ加: 整形外科 24,187 .

4）吉川他：臨床整形外科。 3,783 .

5) 松野: 臨形外科. $3,766$. 
6)西尾：臨床整形外科. 3, 796.

7）柏木ほ加：臨床整岀外科。3，774。

質 問州労災病院整形 野村 茂治

(1) 乙の手術で後療法はいつまで続けられるのか.

(2) 手術侵襲が大きいために術後㱂痕が大きくなり

Rigid な足になる心配はないか.

(3) この手術をすれば再発の心配はないのか.

(4) 抄録に内転凹足が矯正出来ないとあるが，内転 凹足変形をとるのがこの手術ではないのか.

(5) 術後矯正靴を使用するとのととであるが，矯正 靴に何を期待するのか. あし期待するとてろが少ない のであれば使用する必要はないのではないか.（矯正 靴がしばしば変形矯正不良な足をかくす目的で使用さ れる恐れあり)

\section{解 答}

(1) 後療法：4 カ月のギプス固定とその後の矯正靴 装用である．矯正靴装用 はそれ程重要視していない が，正規の靴という意味で使っている．（重要視して いない鞭なら使わなくてもよい）という質問に対し： 内反足治療に全くの自信をむってやっているわけでな く，追試者は原著者の意思になるべく沿うようにまづ は努めるべきであろうと考えてやっているのである.

(2) 小さいうちに広汎な op. をやると rigid foot になるのではに対し：内反足そのものがもつ硬さと op. による硬さを区別する方法を知らない. 小さいう ちにやれば年長児でやったものより術後は柔かいので はないかと思う.

(3) 再発がないと断言はできないが，従来いわれて いる再発は変形遺残の顕性化であろうとの考えから, 本法を施行しできるだけ解剖学的骨配列にしょうと考
えたのである. 再発に関しては将来解答がでるであろ う.

(4) 内転, 凹足変形は本来中足部の変形で, 中足部 に手を加えないため矯正できないといったわけで，後 足部に起因する内転変形は当然矯正される.

\section{抄 録}

先天性内反足難治例に対する 後内側解離術 (Turco)

\section{長崎大学 整形外科} 近藤正行，平田重則，乗松敏晴 楅林好隆，鈴木良平

(目的)

4 年前より先天性内反足難治例に Turco の後内側 解離術を施行している. その 1 年以上経過した症例に ついて検討した.

(方法)

昭和 48 年春より 52 年春までに本法を施行したのは 31 例 44 足で, 1 年以上経過をみたあのは 22 例 31 足 である. 年令は初期の頃は 2 才前後であったが, 最近 では 1 才前後に施行している.

\section{(結果)}

初期の 5 例 5 足, ギプス内でキルシュナー鋼線の抜 けた 1 例 1 足に成績不良例があったがその他の例では ほぼ目的を達することができた.

本法では前凹足部内転, 足変形は矯正できないので それらにはさらに追加手術を要する. 足の成長障害, 下腿筋萎縮などのととを考えるとギプス，補装具によ る矯正を早めにきりあげて手術にうつるべきであろう か. 